Article

\title{
Impact of Soil Amendments on the Hydraulic Conductivity of Boreal Agricultural Podzols
}

\author{
Dinushika Wanniarachchi ${ }^{1}$, Mumtaz Cheema ${ }^{1}$, Raymond Thomas ${ }^{1}$, Vanessa Kavanagh ${ }^{2}$ \\ and Lakshman Galagedara ${ }^{1, *}$ \\ 1 School of Science and the Environment, Memorial University of Newfoundland, \\ Corner Brook, NL A2H 5G4, Canada; dwanniarachc@grenfell.mun.ca (D.W.); \\ mcheema@grenfell.mun.ca (M.C.); rthomas@grenfell.mun.ca (R.T.) \\ 2 Department of Fisheries and Land Resources, Government of Newfoundland, \\ Pasadena, NL A0L 1K0, Canada; VanessaKavanagh@gov.nl.ca \\ * Correspondence: lgalagedara@grenfell.mun.ca; Tel.: +1-709-639-2565
}

Received: 25 May 2019; Accepted: 21 June 2019; Published: 25 June 2019

check for updates

\begin{abstract}
Hydraulic properties of soil are the basis for understanding the flow and transport through the vadose zone. It has been demonstrated that different soil amendments can alter the soil properties affecting soil hydrology. The aim of this study was to determine the effect of soil amendments on hydraulic conductivity $(\mathrm{K})$ of a loamy sand podzolic soil under both unsaturated ( $\left.\mathrm{K}_{\text {unsat }}\right)$ and near-saturated (near $\mathrm{K}_{\text {sat }}$ ) conditions in an agricultural setting. A field experiment was conducted with two common soil amendments: Dairy manure (DM) in 2016 and 2017 and biochar (BC) once only in 2016. DM and BC were incorporated up to a depth of $0.15-0.20 \mathrm{~m}$ at a rate of 30,000 L ha ${ }^{-1}$ and $20 \mathrm{Mg} \mathrm{ha}^{-1}$, respectively. A randomized complete block experimental design was used and the plots planted with silage corn (Zea mays L.) without irrigation. The treatments were: Control without amendment $(0 \mathrm{~N})$, inorganic $\mathrm{N}$ fertilizer (IN), two types of DM (IN+DM1 and IN+DM2), and two treatments with $\mathrm{BC}(\mathrm{IN}+\mathrm{BC}$ and $\mathrm{IN}+\mathrm{DM} 1+\mathrm{BC})$. Infiltration data were collected using a mini disk infiltrometer under three tension levels in which -0.04 and $-0.02 \mathrm{~m}$ was ascribed as unsaturated (at the wet end) and $-0.001 \mathrm{~m}$ as near-saturated condition. Based on the measured infiltration rates, $\mathrm{K}_{\text {unsat }}$ and near $\mathrm{K}_{\text {sat }}$ hydraulic conductivities were calculated. There were no significant effects of DM and $\mathrm{BC}$ on bulk density and near $\mathrm{K}_{\text {sat }}$. Treatments $\mathrm{IN}+\mathrm{DM} 1, \mathrm{IN}+\mathrm{DM} 2$, and IN+DM1+BC significantly reduced the $\mathrm{K}_{\mathrm{unsat}}$ compared to the control. Since these soil amendments can influence soil hydrology such as reduced infiltration and increased surface runoff, carefully monitored application of soil amendments is recommended.
\end{abstract}

Keywords: biochar; dairy manure; hydraulic conductivity; infiltration; podzols; soil amendments

\section{Introduction}

The soil unsaturated zone, also called zone of aeration or vadose zone, is the soil layer above the groundwater table. In agricultural and arable soils, the unsaturated zone provides air, water, and nutrients to plants and soil organisms [1,2]. Hydrologically, the vadose zone controls water and contaminant entry, storage, and movement from the soil surface to the groundwater [3]. Thus, understanding the dynamics of the unsaturated zone is critical for the use and sustainable management of groundwater. Hydraulic properties of soils such as hydraulic conductivity $(\mathrm{K})$ and the moisture retention function are critical for understanding flow and transport through the soil matrix and are important inputs in vadose zone simulations [4,5]. In addition, saturated and unsaturated hydraulic properties of any soil will influence the separation of input water (i.e., precipitation/irrigation) into runoff and infiltration [6]. Unsaturated $\left(\mathrm{K}_{\mathrm{unsat}}\right)$ and saturated $\left(\mathrm{K}_{\mathrm{sat}}\right)$ hydraulic conductivity is a 
measure of how water flows through unsaturated and saturated soil profiles, respectively [7], and $\mathrm{K}_{\text {sat }}$ is often used as an indicator of how water flows through unsaturated soils, which is generally overestimated [1,5].

Synthetic fertilizers are added solely to improve soil fertility; however, the main purpose of using natural soil amendments such as manure and biochar (BC) is to improve overall physical, chemical, and biological properties of soils [8-10].

Dairy manure (DM) and BC are commonly used by farmers worldwide, thus physicochemical and hydraulic properties of agricultural soils are continuously being altered by the use of amendments and other management practices. Previous studies have reported that DM amendments improved the soil tilth and porosity [11], increased soil infiltration rates, $K_{\text {sat }}$ [12,13] crop yields [14], soil organic matter (SOM), and aggregation as well as decreased the soil bulk density $[15,16]$. The addition of BC improved soil chemical properties such as $\mathrm{pH}$ and cation exchange capacity (CEC) due to higher surface area [17], physical properties such as porosity and bulk density [18-21], and provided suitable habitats for microorganisms [22]. Both DM and BC facilitate soil aggregate formation by stimulating microbial and fungal activity, increasing their exudate production, and providing greater binding agents between soil particles [23]. In addition, aromatic components in BC can also contribute to the stabilization of microaggregates when compared to DM [24,25]. Earthworms mix soil amendments such as BC and DM throughout the soil profile and further assist in aggregate stabilization [26]. Soil aggregates are very important in soil property determinations because they prevent rapid biodegradation of SOM, thus enhancing the soil structure and porosity $[27,28]$.

Increased surface area of the solid phase and porosity of soil has been shown to influence the soil structure through changing the overall surface area, amount, size, and distribution of soil pores, and bulk density thus improving soil aeration and soil strength [29,30]. Additional advantages of $\mathrm{BC}$ application to agricultural soils are the reduction in greenhouse gas emissions [31-33] and carbon sequestration [34-36].

Studies reporting the effects of $\mathrm{BC}$ and $\mathrm{DM}$ on $\mathrm{K}_{\text {sat }}$ vary in the literature and those reporting the effects on $\mathrm{K}_{\text {unsat }}$ are very limited and inconclusive, particularly relating to podzolic soils common in boreal ecosystems [37,38]. Generally, podzolic soils are formed from coarse- to medium-textured, acidic parent materials under forest or health vegetation in cool climates. However, these soils can occur in wet sandy sites in areas of subhumid climates and can also be formed from calcareous parent materials. Podzols are distinctively characterized by illuviated B horizons where humified organic matter combined with $\mathrm{Al}$ and Fe accumulation, often overlaid by a light colored eluviated (Ae) horizon [39]. Despite the growing need for food production in cool climatic regions globally and the expansion of agriculture and human population in boreal environments containing podzolic soils, there is limited information available on hydraulic properties and water management of podzolic soils for effective agricultural production in these environments [40].

Amending the soil with different types and rates of DM and BC may have varying and specific influences on soil properties due to the composition and inherent properties of DM and BC amendments. The age and health conditions of the herd and feeding practices can influence the quality and quantity of DM as can the type of bedding, amount of water used in the barn or added to DM, and the type and duration of storage can affect DM composition and properties [41]. The type of biomass used as the feedstock and pyrolysis conditions such as temperature and charring time can affect BC properties as well. Organic soil amendments such as BC and DM may alter the soil properties according to the type of soil and climatic conditions [19,22,42]. Additionally, the aging of these amendments may have different and complex effects on soil properties [43,44]. Since high DM application rates can potentially increase water repellency, localized patches with higher water infiltration potential can also be formed resulting in selective water entry into the soil, stimulating preferential flow paths. Hence, water repellency may bypass the complete wetting of the soil matrix, causing microbial, nutrient, and agrochemical leaching or runoff, subsequently increasing groundwater contamination $[45,46]$. 
Moreover, this localized wetting, leaching, and runoff can cause nutrient deficiency in crops and decreased availability of soil moisture in the rhizosphere [47,48].

Knowledge of the $\mathrm{K}_{\text {unsat }}$ and $\mathrm{K}_{\text {sat }}$ and its variability is essential for describing the infiltration capacity, flow, and solute transport in such soils where soil amendments are added. The main objective of this study was to evaluate the effect of the application of DM and BC as soil amendments on infiltration capacity under both unsaturated and near-saturated conditions in agricultural podzols in a boreal climate. In order to achieve this objective, $K_{\text {unsat }}$ (at -0.04 and $-0.02 \mathrm{~m}$ tension) and near $\mathrm{K}_{\text {sat }}(-0.001 \mathrm{~m}$ tension) were estimated using a mini disk infiltrometer with an emphasis on amending agricultural podzolic soil with DM and BC.

\section{Materials and Methods}

The study was conducted at Pynn's Brook Research Station (PBRS) operated by the Department of Fisheries and Land Resources, Government of Newfoundland and Labrador, Pasadena $\left(49^{\circ} 04^{\prime} 22.6^{\prime \prime} \mathrm{N}\right.$ $\left.57^{\circ} 33^{\prime} 38.9^{\prime \prime} \mathrm{W}\right)$, Canada. Data collected during 30-years (1986-2016) by the Deer Lake weather station and obtained from Environment Canada (http://climate.weather.gc.ca/) shows that the area receives an average precipitation of $1113 \mathrm{~mm}$ per year with less than $410 \mathrm{~mm}$ falling as snow, and has an annual mean temperature of $4{ }^{\circ} \mathrm{C}$. Handheld GPS measurements have indicated an elevation between 43 and $50 \mathrm{~m}$ a.s.l. The reddish brown to brown podzolic soil developed on a gravelly sandy fluvial deposit with $>1.0 \mathrm{~m}$ depth to bedrock with an average slope of $2 \%$ to $5 \%$ [49]. The soil tested is classified as a loamy sand podzol $(73.7 \pm 4.1 \%$ sand $+23.0 \pm 3.8 \%$ silt $+3.3 \pm 0.3 \%$ clay) with an average bulk density of $1.31 \mathrm{~g} \mathrm{~cm}^{-3}( \pm 0.07)$ and porosity of $51 \%( \pm 0.03)$ [40]. The area was tile drained (at $\left.0.75 \mathrm{~m} \mathrm{depth}\right)$ and the depth to the water table (2017 and 2018) varied between 1.58-2.98 m with an average of $2.48 \mathrm{~m}$.

\subsection{Experimental Design and Land Preparation}

The experiment was conducted using a randomized complete block design containing 32 experimental plots each having dimensions of $1 \mathrm{~m}$ width and $5 \mathrm{~m}$ length.

This study was part of a silage-corn (Zea mays L.) varietal trial (2015 to 2017) evaluating the effect of soil amendment on nitrogen $(\mathrm{N})$ losses and greenhouse gas emission. There were eight treatments within the main experiment and each treatment was replicated four times. However, only six treatments were considered for this study and included amendments using two types of DM according to their total $\mathrm{N}$ and total phosphorous $(\mathrm{P})$ contents [DM1 with high $\mathrm{N}(0.44 \%), \mathrm{P}(0.08)$ and DM2 with low $\mathrm{N}(0.12 \%), \mathrm{P}(0.01 \%)]$ and granular $\mathrm{BC}$ produced by slow pyrolysis at $500{ }^{\circ} \mathrm{C}$ for $30 \mathrm{~min}$ of Yellow pine wood (Pinus taeda). The six treatments used in this study were: N0 (no N-control), IN (inorganic $\mathrm{N}), \mathrm{IN}+\mathrm{DM} 1, \mathrm{IN}+\mathrm{DM} 2, \mathrm{IN}+\mathrm{BC}$, and IN+DM1+BC. Tables 1 and 2 show the basic properties and characteristics of $\mathrm{BC}$ and $\mathrm{DM}$ used in this study. The field was ploughed with a spring disc for seed bed preparation. DM (in both 2016 and 2017) was applied at a rate of 30,000 $\mathrm{L} \mathrm{ha}^{-1}$ according to local agricultural practice (surface broadcasting of a liquid slurry) and additional inorganic $\mathrm{N}$ was applied to fulfill the $\mathrm{N}$ requirements of the crop. BC (only once in 2016) was incorporated at a rate of $20 \mathrm{Mg} \mathrm{ha}^{-1}$ and thoroughly mixed within the top $0.15-0.20 \mathrm{~m}$ of the soil. Silage corn was seeded (at a rate of 90,900 seeds $\mathrm{ha}^{-1}$ ) using a SAMCO system (SAMCO Agricultural Manufacturing, Ireland). This system was also used to cover the seeded fields with plastic sheets. The plastic sheet provided additional heat units to enhance seedling germination and establishment during early growth stages of silage corn in cool climate production systems [50]. The field was not irrigated, thus the crop relied solely on seasonal precipitation. The infiltration tests were carried out in the middle of the growing season when the crop was at the tasseling stage (4-22 August 2017). 
Table 1. Basic properties of biochar used in the study.

\begin{tabular}{ccc}
\hline Feedstock & Unit & Yellow Pine Wood (Pinus taeda) \\
\hline Particle size & $\mathrm{mm}$ & $1-6$ \\
Bulk Density & $\left(\mathrm{g} \mathrm{cm}^{-3}\right)$ & 0.20 \\
Moisture & $\%$ & 15.2 \\
$\mathrm{pH}(1:$ 10 BC: Water $)$ & - & 9.0 \\
EC $(1: 10)$ at $21-22{ }^{\circ} \mathrm{C}$ & $\left(\mathrm{dS} \mathrm{m}^{-1}\right)$ & 5.2 \\
Fixed carbon & $\%$ & 87.3 \\
Volatile Carbon $\left(600{ }^{\circ} \mathrm{C}\right)$ & $\%$ & 12.7 \\
Ash & $\%$ & 6 \\
\hline
\end{tabular}

Table 2. Basic characteristics of two types of dairy manure used in the study [51].

\begin{tabular}{ccc}
\hline Characteristic (as Received Basis) & DM1 & DM2 \\
\hline Dry matter (\%) & 10.90 & 1.70 \\
pH & 6.80 & 7.10 \\
Total Nitrogen (\%) & 0.44 & 0.12 \\
Total Phosphorus (\%) & 0.08 & 0.01 \\
Total Potassium (\%) & 0.37 & 0.12 \\
Total Calcium (\%) & 0.19 & 0.04 \\
Total Magnesium (\%) & 0.07 & 0.01 \\
Total Iron $\left(\mathrm{mg} \mathrm{kg}^{-1}\right)$ & 68.00 & 7.00 \\
Total Manganese $\left(\mathrm{mg} \mathrm{kg}^{-1}\right)$ & 21.00 & 5.00 \\
Total Copper $\left(\mathrm{mg} \mathrm{kg}^{-1}\right)$ & 4.50 & 20.00 \\
Total Zinc $\left(\mathrm{mg} \mathrm{kg}^{-1}\right)$ & 21.00 & 5.00 \\
Total Boron $\left(\mathrm{mg} \mathrm{kg}^{-1}\right)$ & 3.40 & 0.50 \\
Total Sodium $\left(\mathrm{mg} \mathrm{kg}^{-1}\right)$ & 904.00 & 241.00 \\
\hline
\end{tabular}

\subsection{Infiltration Tests and Measurements}

There are a number of experimental and empirical methods used on both field and laboratory scales to determine the soil $\mathrm{K}$. The use of the mini disk infiltrometer (a tension infiltrometer) is one such method that has been developed to measure field $\mathrm{K}[52,53]$.

In this study, the mini disk infiltrometer (METER Group Inc., WA, USA) was used to estimate $K_{\text {unsat }}$ of the surface soil. This instrument has been used to determine $K_{\text {unsat }}$ of soils in various studies including different plant covers and soil types [54,55]. The tension infiltrometer can be used to estimate the $K_{\text {unsat }}$ by measuring the soil infiltration at different applied tension levels. These tension levels generally are in the wet end of most agricultural soils $(-0.005$ to $0.06 \mathrm{~m})$ to measure $\mathrm{K}_{\text {unsat }}$ avoiding macropore (cracks or wormholes) flows. The instrument consists of a water reservoir, a mariotte tube, a bubble chamber, a tension control tube, and a porous sintered stainless-steel contact disc, $4.5 \mathrm{~cm}$ in diameter and $3 \mathrm{~mm}$ in thickness (METER Group Inc., WA, USA). The operating principle is based on releasing water from the infiltrometer to the soil surface under a controlled tension. The controlled tension in the infiltrometer is managed by the mariotte tube in the bubble chamber and the porous stainless-steel plate. Therefore, only soil pores with matric potential lower than the applied tension (or higher soil suction) can be filled. Infiltration is carried out until constant infiltration rates are achieved [56]. Using this technique, $\mathrm{K}_{\mathrm{unsat}}$ in the soil matrix can accurately be estimated eliminating preferential flow caused by cracks, bio-macropores, and other structures [56,57].

After filling the bubble chamber and water reservoir with water, the mini disk infiltrometer was placed on a levelled sampling soil surface prepared with a thin layer of fine sand to facilitate good contact with the stainless-steel plate. The soil surface was cleared of vegetation and levelled to a smooth horizontal surface to ensure even contact with the infiltration disc.

The infiltration tests were carried out at the three tension levels of $-0.04,-0.02$, and $-0.001 \mathrm{~m}$ in a sequence of high to low tensions. Based on the texture of the soil, the recommended tension level was 
$-0.02 \mathrm{~m}$ for $\mathrm{K}_{\text {unsat }}$ measurements (METER Group Inc., Pullman, WA, USA); however, $-0.001 \mathrm{~m}$ was assumed to be close to near $\mathrm{K}_{\text {sat }}$ and other tension levels such as $-0.06,-0.04$, and $-0.01 \mathrm{~m}$ were also tested. The initial readings were taken at all tension levels. As the water infiltrated, the water level in water reservoir was recorded at regular time intervals of $30 \mathrm{~s}$, except for measurements at $-0.001 \mathrm{~m}$ which were recorded at $15 \mathrm{~s}$ because of the increased rate of infiltration under $-0.001 \mathrm{~m}$ tension. Each treatment was replicated four times, and for each treatment plot, infiltration tests were carried out in three different locations, and the average $K_{\text {unsat }}$ and near $K_{\text {sat }}$ was calculated. This experiment was carried out during the middle of the growing season and assumed that soil surface in each plot had settled after initial plowing and incorporation of DM and BC. We selected each location (three locations per plot) for the infiltration experiment after carefully observing the surface and selected less disturbed (well settled) surfaces. This allowed us to ensure that the infiltration was affected by the treatment only and not by other surface disturbances.

The resulting time and cumulative infiltration data were entered into a Microsoft Excel Macro Workbook provided by the manufacturer (Meter Group Inc., Pullman, WA, USA) to calculate $K_{\text {unsat }}$ using the method proposed by Zhang [5]. Cumulative infiltration (I) was calculated using Equation (1).

$$
I=C_{1} t+C_{2} \sqrt{t}
$$

where $C_{1}$ is a parameter related to $K\left(\mathrm{~m} \mathrm{~s}^{-1}\right)$ and is the slope of the relationship between $I$ and $\sqrt{ } t$ (Equation (2)), $C_{2}$ is soil sorptivity $\left(\mathrm{m} \mathrm{s}^{-1 / 2}\right), t$ is the infiltration time (s). The $K$ for the soil is then computed from Equation (2).

$$
K=\frac{C_{1}}{A}
$$

$A$ is computed as in Equation (3) and is related to the van Genuchten parameters for a specific soil type to the tension rate and the radius of the infiltrometer disk,

$$
A=\frac{11.65\left(n^{0.1}-1\right) \exp \left[2.92(n-1.9) \propto h_{0}\right]}{\left(\propto r_{0}\right)^{0.91}}
$$

where $n$ and $\alpha$ are the van Genuchten parameters [58], $r_{0}$ is the radius of the infiltrometer's disk $(22.5 \mathrm{~mm})$, and $h_{0}$ is the tension at the infiltrometer's disk surface.

Soil moisture release curves were developed by collecting disturbed soil samples from IN, IN+BC, IN+DM1, and IN+BC+DM1 treatment plots. Disturbed soil samples were collected from a depth of 0 to $0.15 \mathrm{~m}$ at three locations for each treatment plots but only from two replicates. Samples from three locations in each plot were mixed together and a composite sample was prepared and then oven-dried at $105{ }^{\circ} \mathrm{C}$ for $24 \mathrm{~h}$. After removing large stones and other inert materials, repacking of samples in pressure plate rings or tension funnels for conducting the hanging water column methods was done according to the field-measured bulk density value obtained from each treatment. Bulk density was measured by collecting undisturbed soil core samples and dividing the dry soil mass by the core volume [40]. Porosity and saturated water content were determined first by estimating the volume of water needed to saturate the air-dried samples. At lower tension levels from 1 to $8 \mathrm{kPa}$, data were collected using the hanging water column method, and from 20 to $1000 \mathrm{kPa}$, data were collected using the pressure plate apparatus. Field capacity (FC) values were obtained at $20 \mathrm{kPa}$, and permanent wilting point values (PWP) were obtained at $1000 \mathrm{kPa}$ (we could not obtain values for $10 \mathrm{kPa}$ and $1500 \mathrm{kPa}$ using the pressure plate). Based on saturation, FC, and PWP values, macro pore volume (MPV) (drainable porosity), and available water content (AWC) were calculated.

\subsection{Statistical Analysis}

Statistical analyses were carried out using Minitab $17^{\circledR}$ statistical software package (C)Minitab Inc. at http://www.minitab.com/en-us/). The data were checked for normality (Anderson-Darling test) and outliers (Grubb's test). To identify differences in computed $\mathrm{K}_{\mathrm{unsat}}\left(\mathrm{cm} \mathrm{s}^{-1}\right)$ among the six treatments 
under three tension levels, one-way analysis of variance (ANOVA) and Tukey's tests were carried out at a $95 \%$ confidence level.

\section{Results and Discussion}

According to the Anderson-Darling test and Grubb's test, the data were normally distributed without outliers. The average bulk density of the field plots under different treatments ranged from $1.19-1.49 \mathrm{~g} \mathrm{~cm}^{-3}$ (Figure 1). Only IN+DM1 and IN+BC plots had significantly lower $(p=0.017$ and $p=0.013$, respectively) bulk density compared to the control. This was around a $20.0 \%$ reduction (DM1 $-19.7 \%$ and IN+BC-20.3\%) of the bulk density in comparison to the control treatment. On the other hand, IN+DM1+BC treatment reduced the bulk density by $11.0 \%$ but was not statistically significant $(p=0.302)$. Due to the significant differences in bulk density among treatments, the change in bulk density was also considered when comparing the treatment effect on $\mathrm{K}$. We observed that the effect of bulk density on the $\mathrm{K}_{\mathrm{unsat}}$ and near $\mathrm{K}_{\text {sat }}$ was not significant for all tension levels tested. Therefore, any effect among treatments could not be attributed to the bulk density ranges observed in this experiment.

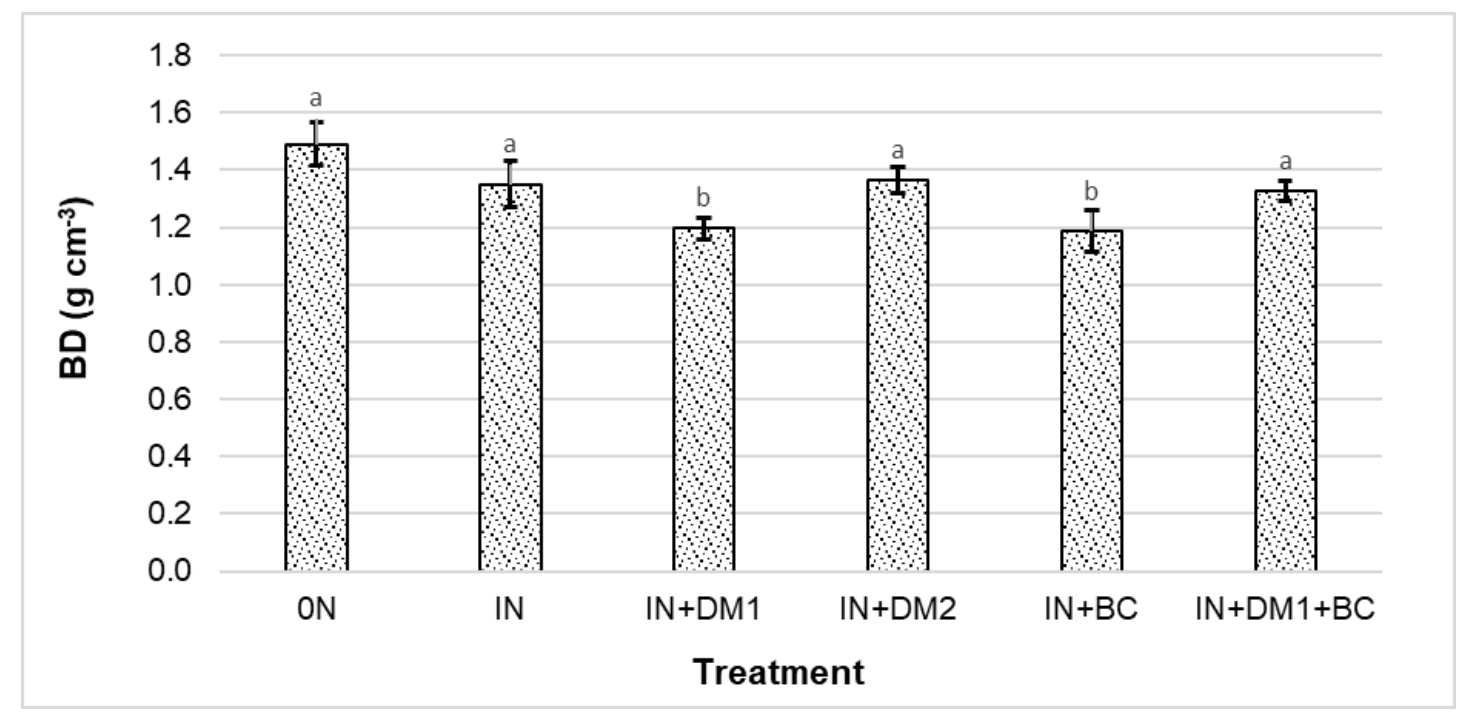

Figure 1. Average bulk density (BD) for field plots for different treatments (error bars show standard error of the mean; $n=36$, alpha $=0.05$ ). $0 \mathrm{~N}$ : No nitrogen (control); IN: Inorganic nitrogen; DM1: Dairy manure 1; DM2: Dairy manure 2; BC: Biochar.

The $\mathrm{K}$ increased with decreasing tension level regardless of the treatment as expected (Figure 2). The IN+DM1 treatment showed significantly reduced $\mathrm{K}$ values compared to the control under -0.04 and $-0.02 \mathrm{~m}$ tensions (IN+DM1: $p=0.005$ and $0.000 ; \mathrm{IN}+\mathrm{DM} 1+\mathrm{BC}: p=0.006$ and 0.001 , respectively). Moreover, IN+DM2 significantly reduced $\mathrm{K}$ under $-0.02 \mathrm{~m}$ tension $(p=0.000)$. There were no significant changes in $\mathrm{K}$ under $-0.001 \mathrm{~m}$ tension, which was assumed as the near-saturated $\mathrm{K}$ at field conditions. However, a relatively high variability of near $\mathrm{K}_{\text {sat }}$ at -0.001 tension for the IN treatment was found. The tested soil was a loamy sand podzol (high sand $=73.7 \pm 4.1 \%$ ) which generally has more macropores (relatively high gravitational water). The reduction in $\mathrm{K}$ in DM treatments might be due to liquid dairy manure clogging the soil pores or changes in soil porosity [59,60]. On the other hand, the difference in $\mathrm{K}_{\text {unsat }}$ values between DM1 and DM2 at $-0.04 \mathrm{~m}$ tension could be mainly due to the difference in dry matter contents between the two DM types (Table 2). However, amended BC did not reduce $\mathrm{K}$ significantly, which might be due to its granular nature (1-6 $\mathrm{mm}$ particle size) and the soil porosity may be less affected by the BC amendment compared to when DM was applied. It is important to note that the infiltration experiments were carried out at the middle of the growing season when the soil surfaces were assumed to be well settled. Indeed, further studies should be carried out 
under controlled conditions to confirm these findings. Previous researchers have reported that high soil heterogeneity at field level as well as different properties of soil amendments can have mixed and complex effects on soil hydraulic properties as discussed at the end of this section.

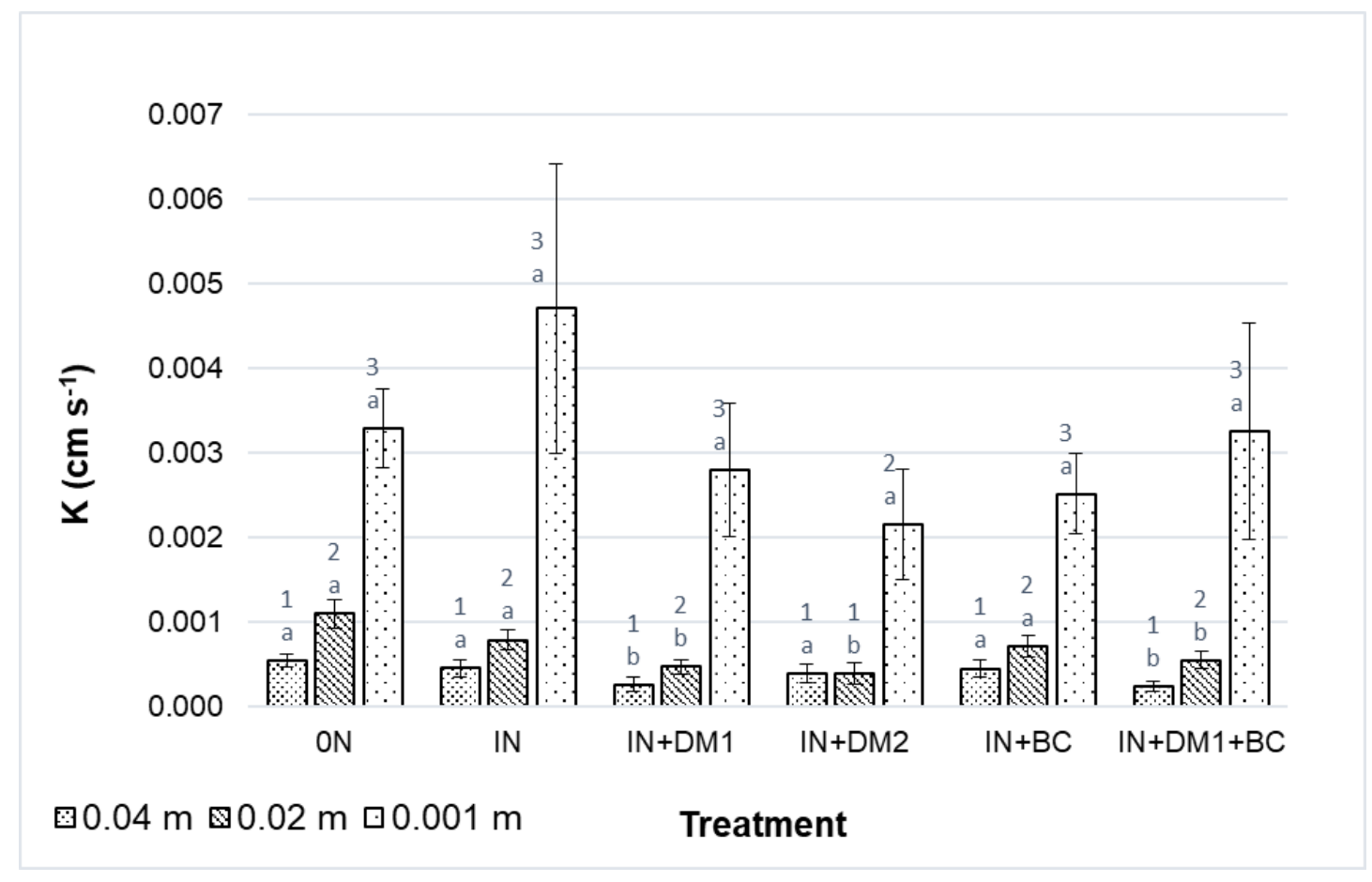

Figure 2. Average field hydraulic conductivity (K) following the addition of biochar (BC) and dairy manure (DM) as soil amendments. Error bars show the standard error of the mean $(n=12$, alpha $=0.05)$. Letters represent significant differences between treatments for a given tension and numbers represent significant difference between tension levels in a given treatment. $0 \mathrm{~N}$ : No nitrogen (control); IN: Inorganic nitrogen; DM1: Dairy manure 1; DM2: Dairy manure 2; BC: Biochar.

Figure 3 shows the soil moisture release curves developed for IN, IN+BC, IN+DM1, and IN+BC+DM1 plots (data are shown only for lower tension levels until $300 \mathrm{kPa}$ ). Saturation (sat), FC, PWP, MPV, and AWC values are shown in Table 3. The highest saturation was observed in the $\mathrm{IN}+\mathrm{DM} 1$ treatment, while the lowest was found in the $\mathrm{IN}+\mathrm{BC}$ treatment. The highest water content at FC and PWP was found in plots treated with both DM and BC, while the highest PAW was found in plots amended with IN. These preliminary results unique sampling indicate that DM and BC may have some effects on macro porosity and available water but cannot be fully confirmed by experimental limitations. However, a clear and systematic relationship could not be observed since we developed only one relationship per treatment. More detailed assessment using undisturbed samples representing different soil depths with replicates are needed to evaluate effects of BC and DM on soil hydraulic properties at a field level. 

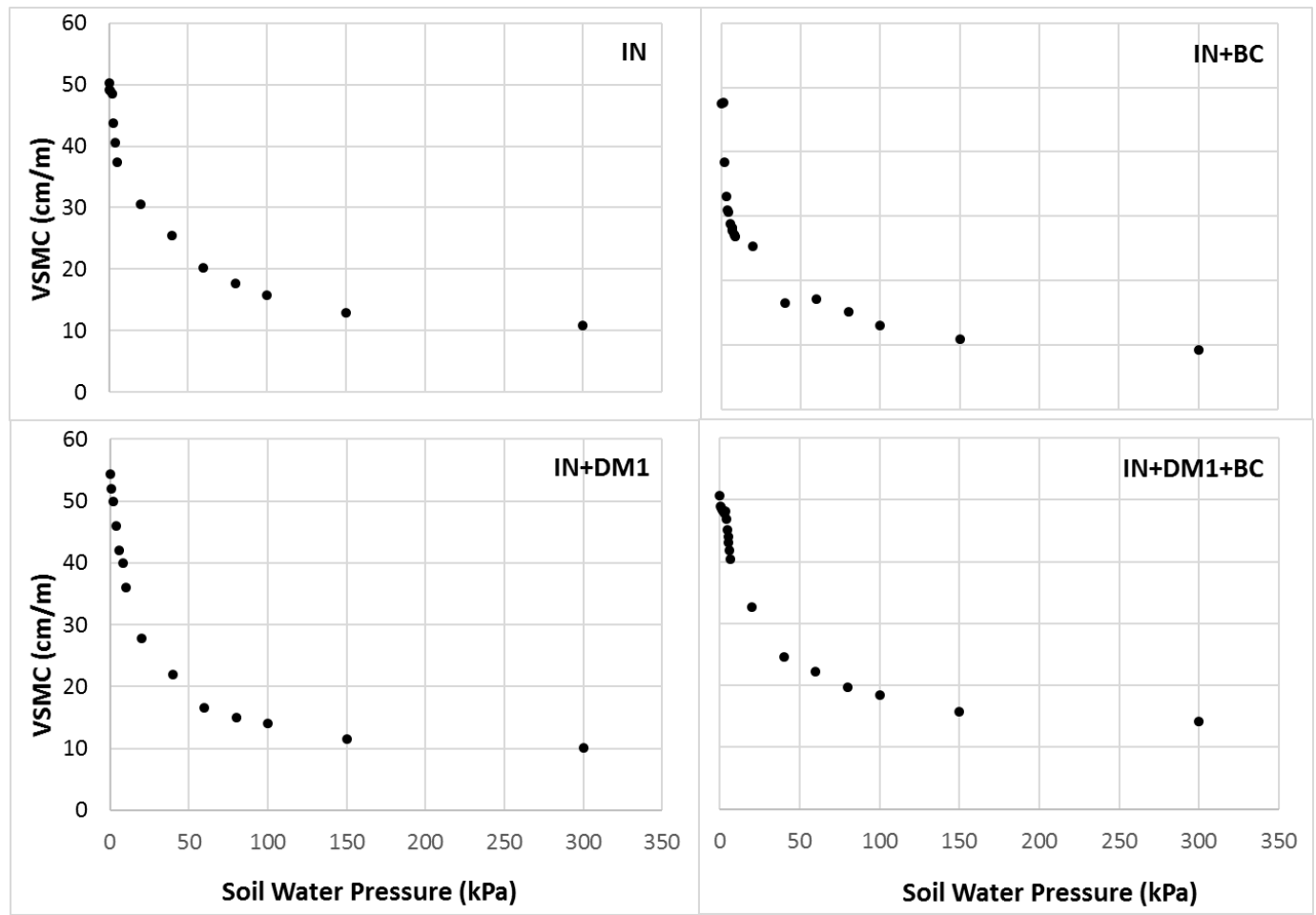

Figure 3. Soil moisture release curves developed for IN, IN+BC, IN+DM1, and IN+BC+DM1 treatments. IN: Inorganic nitrogen; DM1: Dairy manure 1; BC: Biochar.

Table 3. Summary of soil hydraulic properties ( $\mathrm{cm}$ of water per $\mathrm{m}$ of soil) based on the soil moisture release curves.

\begin{tabular}{cccccc}
\hline Treatment & Saturation & FC & PWP & MPV & AWC \\
\hline IN & 50.3 & 30.5 & 7.3 & 19.7 & 23.3 \\
\hline IN+BC & 47.4 & 25.3 & 6.6 & 22.1 & 18.7 \\
\hline IN+DM1 & 54.4 & 27.9 & 6.9 & 26.5 & 21.0 \\
\hline IN+BC+DM1 & 50.7 & 32.6 & 11.3 & 18.1 & 21.4
\end{tabular}

FC: Field Capacity; PWP: Permanent Wilting Point; MPV: Macro Pore Volume; AWC: Available Water Content.

Flow through an unsaturated soil is complex and non-linear and is strongly dependent on the pore geometry, water content, and matric potential [61,62]. Studies reporting the effects of soil amendments on $\mathrm{K}_{\mathrm{unsat}}$ are very few [37,38]. According to Villagra-Mendoza [37], addition of BC enhances soil microporosity, hence enhancing $K_{\text {unsat }}$ at higher matric potentials and rapidly decreasing towards lower potentials of sandy and sandy loam soils. Another study found that long-term manure application had little or no effect on $\mathrm{K}_{\text {unsat }}(-0.3,-0.5,-0.7$, and $-1.0 \mathrm{kPa})$ [38].

Previously reported effects of $B C$ on $\mathrm{K}_{\text {sat }}$ vary due to the variability of soil texture, $B C$ types, rates added, and their maturity in the field. For example, some studies reported that the addition of BC may significantly decrease [63-65] or have no effect $[4,66,67]$ on the $K_{\text {sat }}$ of sandy, loamy-sand, and loamy soils. Conversely, other studies have reported higher $\mathrm{K}_{\text {sat }}$ when $\mathrm{BC}$ is applied because of improvements in the structure and the porosity of the amended soil [29,42].

Furthermore, solid cattle manure amendments significantly increased $\mathrm{K}_{\text {sat }}[68]$ or had no effect after one soil wetting; but increased after two to five wetting and drying cycles [69]. However, it has also been found that liquid cattle manure tends to block the soil pores with fine particles of manure [59,60], thus decreasing the infiltration rates [38] and $\mathrm{K}_{\text {sat }}$ [70]. Moreover, the addition of high quantities (i.e., $90-360 \mathrm{Mg} \mathrm{ha}^{-1}$ ) of cattle manure resulted in surface crusting and decreased 
$\mathrm{K}_{\text {sat }}[60,71]$. Long-term application of heavy rates of manure may cause more unfavorable hydrological conditions, such as increasing water repellency resulting in reduced infiltration and increased surface runoff. Collectively, our findings as well as those reported in the literature indicate that amendments such as DM and BC need to be applied with caution in any agricultural fields including agriculturally used podzols.

\section{Conclusions}

The study evaluated the effect of DM and BC incorporation on hydraulic conductivity of podzolic soils under field conditions in a boreal ecosystem. According to the study results, the treatments containing IN+DM1 and IN+DM1+BC showed significantly reduced $K_{u n s a t}$ values compared to the control under -0.04 and $-0.02 \mathrm{~m}$ tensions, while IN+DM2 significantly reduced $\mathrm{K}_{\text {unsat }}$ under $-0.02 \mathrm{~m}$ tension. There were no significant changes in near-saturated hydraulic conductivity near $\mathrm{K}_{\text {sat }}$ ) under $-0.001 \mathrm{~m}$ tension. Based on results from the literature and this study, we can conclude that long-term and continuous application (or at higher rates) of soil amendments such as DM and BC may cause more unfavorable conditions on soil hydraulic properties, hence need to apply with caution. Further studies are recommended to identify the differences in hydrophobicity and particulate matter in different types and rates of DM and BC amendments and their effects on soil hydrology, particularly podzolic soils used for agriculture production in boreal ecosystems.

Author Contributions: Conceptualization, L.G. and M.C.; Methodology, D.W., L.G., and MC.; Software, D.W.; Validation, L.G., M.C., and R.T.; Formal analysis, D.W.; Resources, L.G., M.C., and V.K.; Data curation, D.W.; Writing-original draft preparation, D.W.; Writing—review and editing, D.W., M.C., R.T., V.K., and L.G.; Visualization, D.W.; Supervision, L.G. and M.C.; Project administration, L.G.; Funding acquisition, L.G.

Funding: This research was funded by Research and Development Corporation of Newfoundland and Labrador, grant number 5404-1962-101 (Ignite R\&D) and the Research Office of Grenfell Campus, Memorial University of Newfoundland through stat-up fund 20160160.

Acknowledgments: Constructive comments given by Adrian Unc during the study are greatly appreciated. Special thanks to the editor of the Journal and the anonymous reviewers for constructive comments and suggestions. We are also grateful to Emmanuel Badewa for his support during the development of soil moisture release curves.

Conflicts of Interest: The authors declare no conflicts of interest. The funders had no role in the design of the study; in the collection, analyses, or interpretation of data; in the writing of the manuscript; or in the decision to publish the results.

\section{References}

1. Tindall, J.A.; Kunkel, J.R.; Anderson, D.E. Unsaturated water flow in soil. In Unsaturated Zone Hydrology for Scientists and Engineers; McConnin, R.A., Ed.; Prentice-Hall, Inc.: Upper Saddle River, NJ, USA, 1999; pp. 183-189.

2. Selker, J.S.; Keller, C.K.; McCord, J.T. An introduction to the vadose zone. In Vadose Zone Processes; CRC Press LLC: Boca Raton, FL, USA, 1999; pp. 3-20.

3. Li, J.; Xi, B.; Cai, W.; Yang, Y.; Jia, Y.; Li, X.; Lv, Y.; Lv, N.; Huan, H.; Yang, J. Identification of dominating factors affecting vadose zone vulnerability by a simulation method. Sci. Rep. 2017, 7, 45955. [CrossRef] [PubMed]

4. $\quad$ Ouyang, L.; Wang, F.; Tang, J.; Yu, L.; Zhang, R. Effects of biochar amendment on soil aggregates and hydraulic properties. J. Soil Sci. Plant Nutr. 2013, 13, 991-1002. [CrossRef]

5. Zhang, R. Determination of soil sorptivity and hydraulic conductivity from the disc infiltrometer. Soil Sci. Soc. Am. J. 1997, 61, 1024-1030. [CrossRef]

6. Eusufzai, M.K.; Fujii, K. Effect of organic matter amendment on hydraulic and pore characteristics of a clay loam soil. Open J. Soil Sci. 2012, 2, 372-381. [CrossRef]

7. Perkins, K.S. Measurement and modeling of unsaturated hydraulic conductivity. In Hydraulic Conductivity, Issues, Determination and Applications; Elango, L., Ed.; Intech Open Limited: London, UK, 2011; pp. 419-434.

8. Traunfeld, J.; Nibali, E. Soil amendments and fertilizers. In Fertilizing Guidelines Included by Plant Group; Home and Garden Information Center, University of Maryland Extension: College Park, MD, USA, 2015. 
9. Page-Dumroese, D.S.; Ott, M.R.; Strawn, D.G.; Tirocke, J.M. Using organic amendments to restore soil physical and chemical properties of a mine site in Northeastern Oregon, USA. Appl. Eng. Agric. 2018, 34, 43-55. [CrossRef]

10. Zhou, L.; Liu, J.H.; Zhao, B.P.; Xue, A.; Hao, G.C. Effects of soil amendment on soil characteristics and maize yield in Horqin Sandy Land. IOP Conf. Ser. Earth Environ. Sci. 2016, 41, 012005. [CrossRef]

11. Whalen, J.K.; Chang, C. Macroaggregate characteristics in cultivated soils after 25th annual manure applications. Soil Sci. Soc. Am. J. 2002, 66, 1637-1647. [CrossRef]

12. Jiao, Y.; Whalen, J.K.; Hendershot, W.H. No-tillage and manure applications increase aggregation and improve nutrient retention in a sandy-loam soil. Geoderma 2006, 134, 24-33. [CrossRef]

13. Eghball, B. Soil properties as influenced by phosphorus-and nitrogen-based manure and compost applications. Agron. J. 2002, 94, 128-135. [CrossRef]

14. Jarvis, S.C.; Scholefield, D.; Pain, B. Nitrogen cycling in grazing systems. In Nitrogen Fertilization in the Environment; Bacon, P.E., Ed.; Marcel Dekker: New York, NY, USA, 1995; pp. 381-419.

15. Benbi, D.K.; Biswas, C.R.; Bawa, S.S.; Kumar, K. Influence of farmyard manure, inorganic fertilizers and weed control practices on some soil physical properties in a long-term experiment. Soil Use Manag. 1998, 14, 52-54. [CrossRef]

16. Darwish, O.H.; Persaud, N.; Martens, D.C. Effect of long-term application of animal manure on physical properties of three soils. Plant Soil 1995, 176, 289-295. [CrossRef]

17. Liang, B.; Lehmann, J.; Solomon, D.; Kinyangi, J.; Grossman, J.; O’Neill, B.; Skjemstad, J.O. Black carbon increases cation exchange capacity in soils. Soil Sci. Soc. Am. J. 2006, 70, 1719-1730. [CrossRef]

18. Abel, S.; Peters, A.; Trinks, S.; Schonsky, H.; Facklam, M.; Wessolek, G. Impact of biochar and hydrochar addition on water retention and water repellency of sandy soil. Geoderma 2013, 202-203, 183-191. [CrossRef]

19. Mukherjee, A.; Lal, R. Biochar impacts on soil physical properties and greenhouse gas emissions. Agronomy 2013, 3, 313-339. [CrossRef]

20. Novak, J.M.; Busscher, W.J.; Watts, D.W.; Amonette, J.E.; Ippolito, J.A.; Lima, I.M.; Gaskin, J. Biochars impact on soil-moisture storage in an Ultisol. Soil Sci. 2012, 177, 310-320. [CrossRef]

21. Chan, K.Y.; Van Zwieten, L.; Meszaros, I.; Downie, A.; Joseph, S. Agronomic values of greenwaste biochar as a soil amendment. Aust. J. Soil Res. 2007, 45, 629-634. [CrossRef]

22. Lopez, V.D. Biochar as a Soil Amendment: Impact on Hydraulic and Physical Properties of an Arable Loamy Sand Soil. Master's Thesis, University of California Merced, Merced, CA, USA, 2014.

23. Six, J.; Feller, C.; Denef, K.; Ogle, S.; de Moraes Sa, J.C.; Albrecht, A. Soil organic matter, biota and aggregation in temperate and tropical soils-Effects of no-tillage. Agron. EDP Sci. 2002, 22, 755-775. [CrossRef]

24. Brodowski, S.; John, B.; Flessa, H.; Amelung, W. Aggregate-occluded black carbon in soil. Eur. J. Soil Sci. 2006, 57, 539-546. [CrossRef]

25. Tisdall, J.M.; Oades, J.M. Organic matter and waterstable aggregrates in soils. J. Soil Sci. 1982, 33, $141-163$. [CrossRef]

26. Topoliantz, S.; Ponge, J.F.; Lavelle, P. Humus components and biogenic structures under tropical slash-and-burn agriculture. Eur. J. Soil Sci. 2006, 57, 269-278. [CrossRef]

27. Sarker, T.C.; Incerti, G.; Spaccini, R.; Piccolo, A.; Mazzoleni, S.; Bonanomi, G. Linking organic matter chemistry with soil aggregate stability: Insight from 13C NMR spectroscopy. Soil Biol. Biochem. 2018, 117, 175-184. [CrossRef]

28. Chaplot, V.; Cooper, M. Soil aggregate stability to predict organic carbon outputs from soils. Geoderma 2015, 243, 205-213. [CrossRef]

29. Major, J.; Rondon, M.; Molina, D.; Riha, S.J.; Lehmann, J. Maize yield and nutrition during 4 years after biochar application to a Colombian savanna oxisol. Plant Soil 2010, 333, 117-128. [CrossRef]

30. Downie, A.; Crosky, A.; Munroe, P. Physical properties of biochar. In Biochar for Environmental Management: Science and Technology; Lehmann, J., Joseph, S., Eds.; Earthscan: London, UK, 2009.

31. Bamminger, C.; Poll, C.; Marhan, S. Offsetting global warming-induced elevated greenhouse gas emissions from an arable soil by biochar application. Glob. Chang. Biol. 2017, 24, 318-334. [CrossRef]

32. Agegnehu, G.; Bass, A.M.; Nelson, P.N.; Bird, M.I. Benefits of biochar, compost and biochar-compost for soil quality, maize yield and greenhouse gas emissions in a tropical agricultural soil. Sci. Total Environ. 2016, 543, 295-306. [CrossRef] [PubMed] 
33. Sackett, T.E.; Basiliko, N.; Noyce, G.L.; Winsborough, C.; Schurman, J.; Ikeda, C.; Thomas, S.C. Soil and greenhouse gas responses to biochar additions in a temperate hardwood forest. GCB Bioenergy 2014, 7 , 1062-1074. [CrossRef]

34. Du, Z.; Zhao, J.; Wang, Y.; Zhang, Q. Biochar addition drives soil aggregation and carbon sequestration in aggregate fractions from an intensive agricultural system. J. Soils Sediments 2017, 17, 581-589. [CrossRef]

35. Nanda, S.; Dalai, A.K.; Berruti, F.; Kozinski, J.A. Biochar as an Exceptional Bioresource for Energy, Agronomy, Carbon Sequestration, Activated Carbon and Specialty Materials. Waste Biomass Valorization 2016, 7, 201-235. [CrossRef]

36. Lin, X.W.; Xie, Z.B.; Zheng, J.Y.; Liu, Q.; Bei, Q.C.; Zhu, J.G. Effects of biochar application on greenhouse gas emissions, carbon sequestration and crop growth in coastal saline soil. Eur. J. Soil Sci. 2015, 66, 329-338. [CrossRef]

37. Villagra-Mendoza, K. Effect of biochar on the unsaturated hydraulic conductivity of two amended soils. Managing Global Resources for a Secure Future. In Proceedings of the Annual Meeting of ASA-CSSA-SSSA, Tampa, FL, USA, 22-25 October 2017.

38. Miller, D.C.; Robinson, J.B.; Gillham, R.W. Selfsealing of earthen liquid manure storage ponds. I. A case study. J. Environ. Qual. 1985, 14, 533-538. [CrossRef]

39. Soil Classification Working Group. The Canadian System of Soil Classification, 3rd ed.; Agriculture and Agrifoods Canada, National Research Council of Canada: Ottawa, ON, Canada, 1998.

40. Badewa, E.; Unc, A.; Cheema, M.; Kavanagh, V.; Galagedara, L. Soil moisture mapping using multi-frequency and multi-coil electromagnetic induction sensors on managed podzols. Agronomy 2018, 8, 224. [CrossRef]

41. Larney, F.J.; Buckley, K.E.; Hao, X.; McCaughey, W.P. Fresh, stockpiled, and composted beef cattle feedlot manure: Nutrient levels and mass balance estimates in Alberta and Manitoba. J. Environ. Qual. 2006, 35, 1844-1854. [CrossRef] [PubMed]

42. Herath, H.; Camps-Arbestain, M.; Hedley, M. Effect of biochar on soil physical properties in two contrasting soils: An Alfisol and an Andisol. Geoderma 2013, 209, 188-197. [CrossRef]

43. Neufeld, K.; Grayston, S.J.; Bittman, S.; Krzic, M.; Hunt, D.E.; Smukler, S. Long-term alternative dairy manure management approaches enhance microbial biomass and activity in perennial forage grass. Biol. Fertil. Soils 2017, 53, 613-626. [CrossRef]

44. Burrell, L.D.; Zehetner, F.; Rampazzo, N.; Wimmer, B.; Soja, G. Long-term effects of biochar on soil physical properties. Geoderma 2016, 282, 96-102. [CrossRef]

45. Kodesova, R.; Nemecek, K.; Zigova, A.; Nikodem, A.; Fer, M. Using dye tracer for visualizing roots impact on soil structure and soil porous system. Biologia 2015, 70, 1439-1443. [CrossRef]

46. Hallett, P.D. An introduction to soil water repellency. In Proceedings of the 8th International Symposium on Adjuvants for Agrochemicals (ISAA2007); Gaskin, R.E., Ed.; International Society for Agrochemical Adjuvants (ISAA): Columbus, OH, USA, 2007.

47. Ward, P.R.; Roper, M.M.; Jongepier, R.; Micin, S.F. Impact of crop residue retention and tillage on water infiltration into a water-repellent soil. Biologia 2015, 70, 1480-1484. [CrossRef]

48. Madsen, M.D.; Petersen, S.L.; Fernelius, K.J.; Roundy, B.A.; Taylor, A.G.; Hopkins, B.G. Influence of soil water repellency on seedling emergence and plant survival in a burned semi-arid woodland. Arid Land Res. Manag. 2012, 26, 236-249. [CrossRef]

49. Kirby, G.E. In Soils of the Pasadena-Deer Lake Area, Newfoundland. 1988. Available online: http: //sis.agr.gc.ca/cansis/publications/surveys/nf/nf17/nf17_report.pdf (accessed on 7 November 2016).

50. Kwabiah, A.B. Growth, maturity, and yield responses of silage maize (Zea mays L.) to hybrid, planting date and plastic mulch. J. New Seeds 2005, 7, 37-59. [CrossRef]

51. Ashiq, W. Evaluating the Potential of Biochar in Mitigating Greenhouse Gases Emission and Nitrogen Retention in Dairy Manure Based Silage Corn Cropping Systems. Master's Thesis, Memorial University of Newfoundland, St. John's, NL, Canada, 2018.

52. Angulo-Jaramillo, R.; Vandervaere, J.-P.; Roulier, S.; Thony, J.-L.; Gaudet, J.-P.; Vauclin, M. Field measurement of soil surface hydraulic properties by disc and ring infiltrometers: A review and recent developments. Soil Tillage Res. 2000, 55, 1-29. [CrossRef]

53. Ankeny, M.D.; Ahmed, M.; Kaspar, T.C.; Horton, R. Simple field method for determining unsaturated hydraulic conductivity. Soil Sci. Soc. Am. J. 1991, 55, 467-470. [CrossRef] 
54. Dohnal, M.; Dusek, J.; Vogel, T. Improving hydraulic conductivity estimates from minidisk infiltrometer measurements for soils with wide pore-size distributions. Soil Sci. Soc. Am. J. 2010, 74, 804-811. [CrossRef]

55. Homolak, M.; Capuliak, J.; Pichler, V. Estimating hydraulic conductivity of a sandy soil under different plant covers using minidisk infiltrometer and a dye tracer experiment. Biologia 2009, 64, 600-604. [CrossRef]

56. Siltecho, S.; Hammecker, C.; Sriboonlue, V.; Clermont-Dauphin, C.; Trelo-ges, V.; Antonino, A.C.D.; Angulo-Jaramillo, R. Use of field and laboratory methods for estimating unsaturated hydraulic properties under different land uses. Hydrol. Earth Syst. Sci. 2015, 19, 1193-1207. [CrossRef]

57. Simunek, J.; van Genuchten, T.M. Estimating unsaturated soil hydraulic properties from tension disc infiltrometer data by numerical inversion. Water Resour. Res. 1996, 32, 2683-2696. [CrossRef]

58. Carsel, R.F.; Parrish, R.S. Developing joint probability distributions of soil water retention characteristics. Water Resour. Res. 1988, 24, 755-769. [CrossRef]

59. Fares, A.; Abbas, F.; Ahmad, A.; Deenik, J.L.; Safeeq, M. Response of Selected soil physical and hydrologic properties to manure amendment rates, levels and types. Soil Sci. 2008, 173, 522-533. [CrossRef]

60. Roberts, R.J.; Clanton, C.J. Surface seal hydraulic conductivity as affected by livestock manure application. Trans. ASABE 2000, 43, 603-613. [CrossRef]

61. Matula, S.; Miháliková, M.; Lufinková, J.; Bát'ková, K. The role of the initial soil water content in the determination of unsaturated soil hydraulic conductivity using a tention infiltormeter. Plant Soil Environ. 2015, 61, 515-521. [CrossRef]

62. Brady, N.C.; Weil, R.R. Elements of Nature and Properties of Soils; Prentice Hall: Upper Saddle River, NJ, USA, 2010.

63. Githinji, L. Effect of biochar application rate on soil physical and hydraulic properties of a sandy loam. Arch. Agron. Soil Sci. 2014, 60, 457-470. [CrossRef]

64. Deveraux, R.; Sturrock, C.; Mooney, S. The effects of biochar on soil physical properties and witner wheat growth. Earth Environ. Sci. Trans. R. Soc. Edinb. 2012, 103, 13-18.

65. Brockhoff, S.R.; Christians, N.E.; Killorn, R.J.; Horton, R.; Davis, D.D. Physical and mineral-nutrition properties of sand-based turfgrass toot zones amended with biochar. Agron. J. 2010, 102, 1627-1631. [CrossRef]

66. Rogovska, N.; Laird, D.A.; Rathke, S.J.; Karlen, D.L. Biochar impact on Midwestern Mollisols and maize nutrient availability. Geoderma 2014, 230, 340-347. [CrossRef]

67. Hardie, M.; Clothier, B.; Bound, S.; Oliver, G.; Close, D. Does biochar influence soil physical properties and soil water availability? Plant Soil 2014, 376, 347-361. [CrossRef]

68. Celik, I.; Ortas, I.; Kilic, S. Effects of compost, mycorrhiza, manure and fertilizer on some physical properties of a Chromoxerert soi. Soil Tillage Res. 2004, 78, 59-67. [CrossRef]

69. Hafez, A.A.R. Comparative changes in soil physical properties inducted by admixtures of manures from various domestic animals. Soil Sci. 1974, 118, 53-59. [CrossRef]

70. Culley, J.L.B.; Phillips, P.A. Sealing of soils by liquid cattle manure. Can. Agric. Eng. 1982, 24, 87-89.

71. Cherobim, V.F.; Favaretto, N.; de Freitas Melo, V.; Barth, G.; Chi-Hua, H. Soil surface sealing by liquid dairy manure affects saturated hydraulic conductivity of Brazilian Oxisols. Agric. Water Manag. 2018, 203, 193-196. [CrossRef]

(C) 2019 by the authors. Licensee MDPI, Basel, Switzerland. This article is an open access article distributed under the terms and conditions of the Creative Commons Attribution (CC BY) license (http://creativecommons.org/licenses/by/4.0/). 